\title{
Florida Plant Disease Management Guide: 'Tahiti' Lime (Citrus latifolia) 1
}

Tara Tarnowski, Aaron J. Palmateer, lan Maguire, and Jonathan H. Crane ${ }^{2}$

\section{DISEASES CAUSED BY FUNGI AND STRAMENOPILES}

\section{MELANOSE}

Melanose (caused by the fungus Diaporthe citri) does not usually cause yield loss, but can at times cause significant financial loss, especially if there is substantial fruit blemishing, resulting in down grading of unsightly fruit to juice production. The fruit blemishes are superficial and do not affect fruit quality. The disease is most prevalent during the rainy season and generally causes more severe damage on flushes in the summer than the spring. Generally, the control program for greasy spot (Mycosphaerella citri) also controls this disease.

\section{Symptoms}

Distinct melanose symptoms occur on leaves, green wood, and fruit. On leaves, melanose lesions begin as small, dark brown to black sunken spots. As the leaf tissue ages, the spots may become raised pustules, with chlorosis that disappears as lesions age
(Figure 1). Symptoms on young, green twigs are quite similar to those on leaves except that they tend to be distinctly raised.

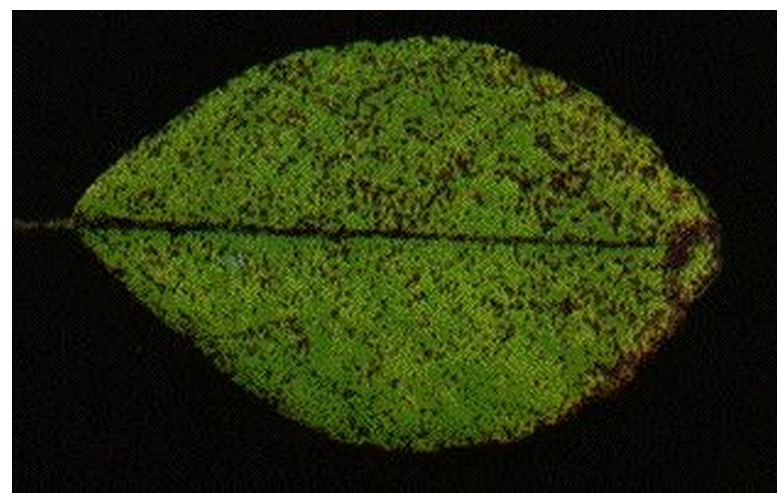

Figure 1.

On fruit, lesions begin as light brown or red circular spots that later become brown to black raised pustules (Figure 2), imparting a sandpaper-like feel to the fruit. If infections become numerous, symptoms appear as large areas of dark, rough scar tissue on the rind that can crack and is referred to as "mudcake". Pustules may occur in a tear-streaked pattern due to

1. This document is PP24, one of a series of the Plant Pathology Department, Florida Cooperative Extension Service, Institute of Food and Agricultural Sciences, University of Florida. Original publication date December 1993. Reviewed April 2003. Revised October 2009. Visit the EDIS Web Site at http://edis.ifas.ufl.edu.

2. Tara Tarnowski, graduate research assistant, Department of Plant Pathology, Tropical Research and Education Center (TREC)--Homestead FL; Aaron J. Plamateer, assistant professor, Department of Plant Pathology, TREC--Homestead FL; Ian Maguire, biological scientist, TREC--Homestead FL; Jonathan H. Crane, professor, Department of Horticultural Sciences; TREC--Homestead FL; Florida Cooperative Extension Service, Institute of Food and Agricultural Sciences, University of Florida, Gainesville, FL 32611.

The Institute of Food and Agricultural Sciences (IFAS) is an Equal Opportunity Institution authorized to provide research, educational information and other services only to individuals and institutions that function with non-discrimination with respect to race, creed, color, religion, age, disability, sex, sexual orientation, marital status, national origin, political opinions or affiliations. U.S. Department of Agriculture, Cooperative Extension Service, University of Florida, IFAS, Florida A. \& M. University Cooperative Extension Program, and Boards of County Commissioners Cooperating. Millie Ferrer-Chancy, Interim Dean. 
the dispersal of spores in water running down the fruit surface.

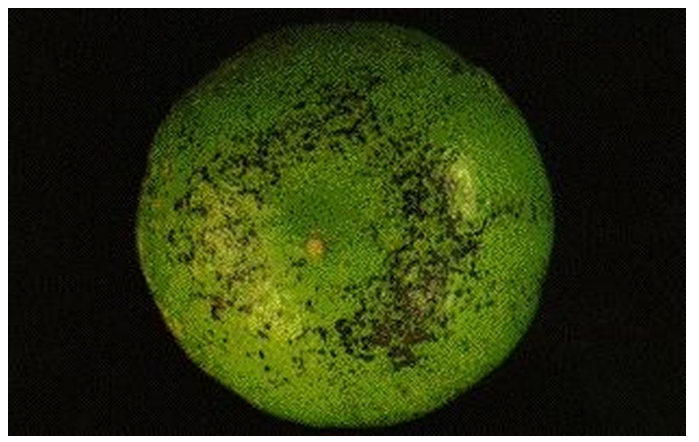

Figure 2.

\section{Causal organism}

Diaporthe citri (anamorph: Phomopsis citri) produces pycnidia (flask-shaped black structures) in dead twigs. Two types of conidia (asexual spores) are produced: small elliptical, hyaline alpha conidia containing an oil droplet at each end, and long filiform beta conidia. The fungus is easily cultured on potato dextrose agar, where it produces colonies with dense, white mycelia. Flask-shaped sexual structures called perithecia can be recovered from dead twigs subsequent to pycnidia production. They contain two-celled, hyaline asocspores with an oil droplet at each end.

\section{Disease cycle and epidemiology}

The fungus completes its life cycle in dead wood tissue. Spores of the melanose fungus are produced in pycnidia that develop only in dead wood. The spores are embedded in a sticky matrix and, for all practical purposes, are released only by splashing rainfall, after which they can infect young leaves, green twigs, and fruit. Subsequent lesions on living tissue do not serve as inoculum sources because no fruiting structures are formed in them. Fruit remain susceptible for approximately 3 months after bloom in Florida. High temperature and prolonged periods of wetness are required for infection. Melanose tends to be more severe in groves with lots of dead wood, such as older groves, groves that are not well maintained or that have trees with frost damage.

\section{Management}

Since dead wood is the primary source of melanose spores, removal of dead wood is a significant control factor. It is important to note that serious out breaks of melanose usually occur after freezes that result in a lot of dead wood in groves. While pruning may not be feasible on older trees, removal of frost-damaged limbs in younger groves can decrease disease incidence. Copper fungicides are important in controlling melanose on fruit, especially those applied during the rainy season. It is not effective in controlling the disease on foliage; fungicides should be applied frequently as the fruit are expanding to ensure proper coverage of the fruit surface.

\section{GREASY SPOT}

Greasy spot, caused by the fungus Mycosphaerella citri, is a major disease of "Tahiti" lime. Severe defoliation, resulting in substantial yield reductions and subsequent long-term loss of tree vigor can result if it is not adequately controlled. For more information, see PP154: Greasy Spot http://edis.ifas.ufl.edu/CH015.

\section{Symptoms}

Fungal invasion occurs through stomata on the underside of the leaves. The first symptoms begin as small, localized waterlogged areas on the underside of leaves. Yellow mottling appears on the upper leaf surface, accompanied by orange to yellow blisters opposite to the mottling on the underside surface (Figure 3). With time, infections turn dark brown to black, with a definite greasy appearance (Figure 4), and chlorosis disappears. Infected leaves very often drop prematurely, leading to large-scale defoliation. The fungus also causes a greasy spot rind blotch, which is characterized by necrotic specks on the fruit surface, but this disease is not commonly seen on lime.

\section{Causal Agent}

Mycosphaerella citri (anamorph: Stenella citri-grisea) forms sexual fruiting structures (pseudothecia) only after diseased leaves have fallen and begin to decompose. Dark pseudothecia appear in 


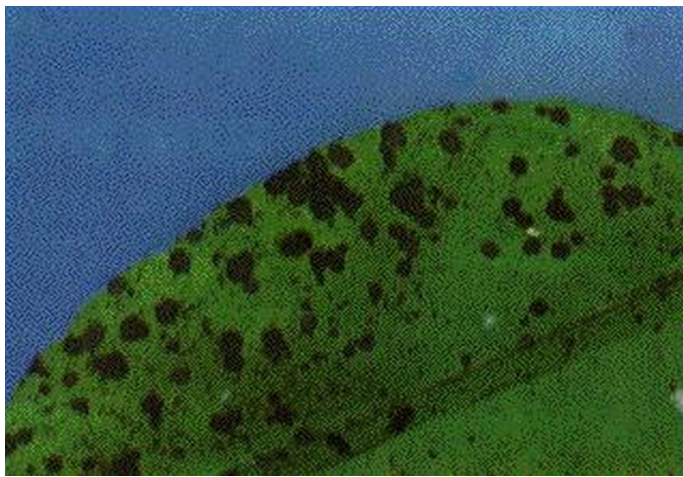

Figure 3.

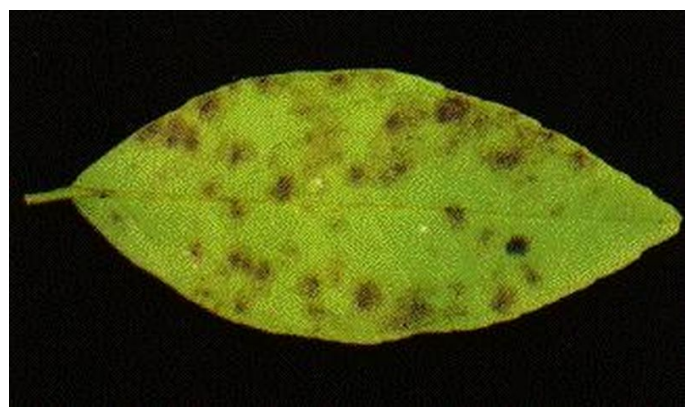

Figure 4.

tight clumps, and produce hyaline, fusiform, single septate ascospores.

Conidia are produced on mycelia colonizing the leaf surface, and are olive brown, septate, and verricose (long and thin). The fungus can be cultured on most media, and forms a slow growing, dark grey to green colony.

\section{Disease cycle and Epidemiology}

Infection of new leaves occurs from invasion by ascospores released during periods of wetness in diseased and decomposing lime leaves on the grove floor. Maximum ascospore production occurs in Florida from April-May, although peak infection likely occurs later (June-September), when humidity and temperatures are higher. The fungus infects mature leaves through the stomata, and symptoms take 45-60 days to develop. There is evidence that the disease is exacerbated when there are high population levels of rust mites or honey dew-producing insects (aphids, whiteflies, mealy bugs). Fruit infection can occur on "Tahiti" lime, but does not seem to be that common.

\section{Management}

Effective control of greasy spot can be obtained with well-timed sprays of copper fungicides or horticultural oil. A single spray in May-June is usually effective in controlling the disease, although in groves where greasy spot is severe a second spray in August can be added.

Because leaf litter provides inoculum for the disease, rapid decomposition of fallen leaves is desirable. Mowing leaf litter can speed up decomposition. Application of urea fertilizer has been shown to reduce ascospore production. However, the efficacy of these measures is questionable because even low levels of inoculum can cause disease epidemics.

\section{SCAB}

The fungus Elsinoe fawcetti causes scab. 'Tahiti' lime is not as susceptible to scab as some other citrus. However, sporadic outbreaks can cause economic loss. The disease is most common in groves where 'Tahiti' lime has been grafted onto rough lemon rootstock. Rough lemon is extremely susceptible to this fungus and inoculum can build up on suckers arising at the base of the tree.

\section{Symptoms}

Infections on lime leaves appear as light-colored, raised areas. Older lesions can become warty. Severely infected leaves are distorted. Infections of fruit appear as prominent, light-colored, raised areas (Figure 5) that throw fruit out of grade. Pustules can be differentiated from mechanical damage in that they are circular and that they often occur in a pattern that follows water flow over the fruit surface.

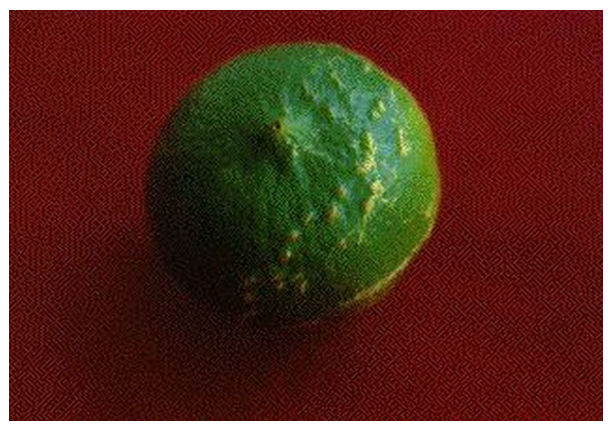

Figure 5. 


\section{Causal organism}

Elsinoe fawcetti produces two types of conidia in acervuli (asexual structures) on the lesion surface. These are hyaline and aseptate, or colored and spindle-shaped. In culture the fungus produces a slow-growing tan or beige colony.

\section{Disease cycle and Epidemiology}

Conidia spread by rain splash to susceptible tissue. Only newly emerging leaves are susceptible; fruit are susceptible until 6-8 weeks after petal fall. Optimum temperature for infection is $75-80^{\circ} \mathrm{F}$ $\left(24-27^{\circ} \mathrm{C}\right)$ and only short periods of wetness are required (several hours), which means dew periods may be sufficient for infection and disease development. Long distance disease dispersal occurs on equipment and especially infested nursery stock.

\section{Management}

Cultural controls are very important in management of scab. If rough lemon has been used as the rootstock, emerged lemon sprouts must be promptly pruned out. Use of air layers will eliminate the rough lemon problem. Overhead irrigation can increase disease severity. Pruning summer flushes can decrease the inoculum densities. There are several fungicides labeled for scab control (see Fungicide Table). A spray at petal drop and several weeks later are usually effective in controlling scab. In heavily infested groves, a third spray can be added after the spring leaf flush.

\section{PHYTOPHTHORA ROT}

Phytophthora spp. cause several important diseases on citrus roots (root rot), trunks (foot rot or gummosis), and on fruit (brown rot). Root rot and foot rot can lead to trees that lack vigor, decreased yields, and even tree death. Brown rot can affect high percentages of fruits.

\section{Symptoms}

Aboveground symptoms of root rot include a thin canopy, lack of new growth, and reduced yields. Fibrous roots are rotted and often have a softened and discolored cortex, which may slough off leaving only the vascular tissue. Severe root rot can cause death of small trees.

Foot rot, also known as gummosis, occurs most often at the point where the scion joins the rootstock, causing a canker that can extend down to susceptible rootstocks and up the trunk. The bark initially softens and the wood underneath is discolored. Eventually the bark cracks and citrus gum is secreted (gummosis). Lesions can spread around tree trunks, eventually girdling and killing the tree (Figure 6). Affected trees may display pale green leaves with yellow veins, defoliation, and dieback.

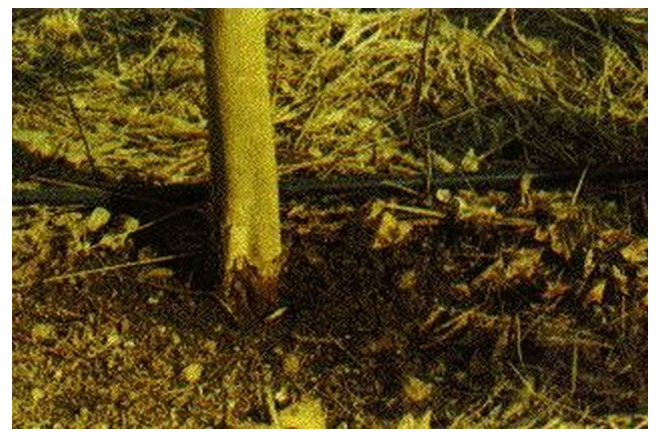

Figure 6.

Brown rot lesions on fruit are tan and leathery. Fruit near the ground are affected first, and then the disease can spread throughout the canopy.

\section{Causal organism}

Both $P$. palmivora and $P$. nicotianae are prevalent in Florida; with $P$. palmivora causing severe brown rot epidemics and $P$. nicotianae only causing root rot and foot rot. Both species produce pear-shaped sporangia that can release motile, biflagellate zoospores under wet conditions, thick-walled, circular chlamydospores, and thick-walled, sexual spores called oospores. Isolates can be recovered from soil using fruit piece baits or PARPH media.

\section{Disease cycle and Epidemiology}

Root rot occurs during periods when soil is wet or flooded, and pathogen populations are maintained on fibrous roots. During wet periods, sporangia release zoospores that are attracted to wounded roots or zones of root elongations. The pathogen can survive for long periods of time in root debris as oospores or chlamydospores. Root rot is more severe 
when $P$. palmivora is present in conjunction with the weevil Diaprepes abbreviatus. Trees on Swingle citrumelo rootstock are more susceptible to the Phytophthora-Diaprepes (PD) complex. For more information on the PD complex see extension bulletin 2009 Florida Citrus Pest Management Guide: Citrus Root Weevils http://edis.ifas.ufl.edu/CG006

Foot rot occurs when trunks are infected through wounds or cracks in the bark. The lesions do not produce new inoculum, so are not able to spread the disease from the original trunk lesion.

Brown rot occurs in the rainy season when sporangia/zoospores are splashed onto low-hanging fruit by rain. These infections eventually sporulate and infect new fruit, and eventually the entire canopy can be affected.

\section{Management}

Control of foot rot is primarily cultural. Nurseries should use pathogen-free seed and potting mix. It is important to prevent disease entry into groves by strict sanitation in the propagation nursery. Irrigation should be timed to avoid overwatering. Rootstocks have varying degrees of tolerance to foot rot. Rough lemon and sweet orange are susceptible and tangerines, tangerine hybrids, citranges, and trifoliate orange are more tolerant.

To avoid foot rot, the bud union should be planted well above the soil line and weeds should be adequately controlled to prevent moisture from building up around tree trunks. Mechanical injury to tree trunks should be avoided, because they can be sites for pathogen entry.

Fungicides can be affective in certain circumstance, depending on pathogen density, grove history, and susceptibility of rootstocks. For more information on factors influencing spray regimes, see PP156: 2009 Florida Citrus Pest Management Guide: Phytophthora Foot Rot and Root Rot http://edis.ifas.ufl.edu/CG009.

\section{SOOTY MOLD}

Sooty mold is not, strictly speaking, a "disease" of lime, since it does not involve the invasion and colonization of the host by a pathogenic microorganism. Instead, it occurs in conjunction with an attack by pest insects such as scales and the citrus whitefly. When whiteflies and related insects feed on lime leaves and fruit, they secrete sweet, sticky honeydew that is promptly invaded by the sooty mold fungus. The result is a black discoloration (due to the color of the fungus) over leaf (Figure 7) and fruit surfaces. Sooty mold can be identified by the fact that it can usually be rubbed off of the plant surface.

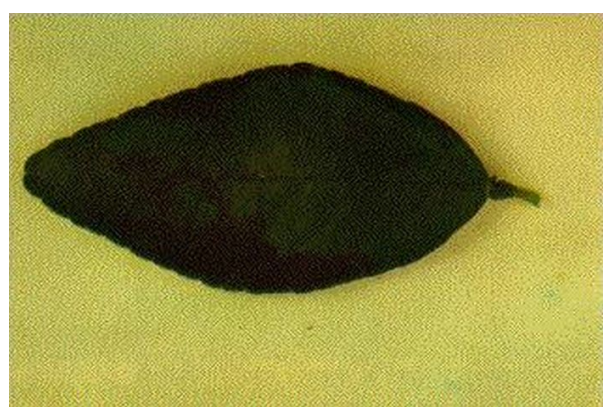

Figure 7.

It is thought that sooty mold has little, if any effect on the general health of the lime tree, and it is considered of economic importance only when the black growth builds up to a point where it cannot be easily cleaned off fruit at the packinghouse. Heavy colonization on leaf surfaces could lead to decreased photosynthetic capacity, which could results in lowered yields.

\section{Diseases caused by bacteria}

\section{Canker}

Canker is one of the most serious diseases of citrus, causing yield losses that can lead to abandonment of citrus cultivation in some areas. 'Tahiti' lime is less susceptible than other types of citrus, and younger trees are at the most risk from the disease. With proper management practices, the crop can be grown successfully in areas where the disease is present. The bacterium attacks leaves, twigs and fruit.

\section{Symptoms}

Lesions become visible 7-10 days after infection, and are first seen on the underside of leaves. Lesions begin on leaves as circular, pinpoint spots and enlarge to lesions of varying size, depending on environmental conditions. Lesions become raised, 
corky pustules, especially on the under-side of leaves, and eventually the center of the lesion sinks so that pustules are crater shaped (Figure 8). These depressed areas occasionally drop from the leaf, leaving lesions with a shot hole appearance. A yellow halo can often be seen on younger lesions, but fades as the lesion ages (Figure 9). Water soaking around lesion margins is also typical of canker. Lesions on limes tend to be darker in color than on other citrus crops. Lesions are often aggregated along leaf margins or tips.

Canker severity is exacerbated by the presence of the Asian leaf miner (Phyllocnistis citrella) because lesions found along feeding galleries often coalesce to form large diseased areas (Figure 10).

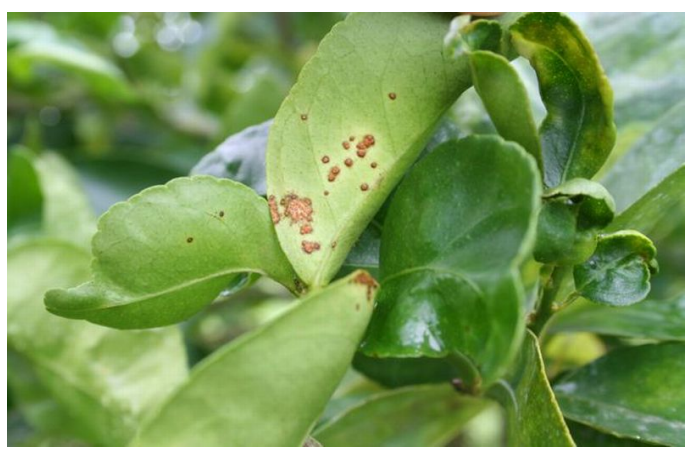

Figure 8.

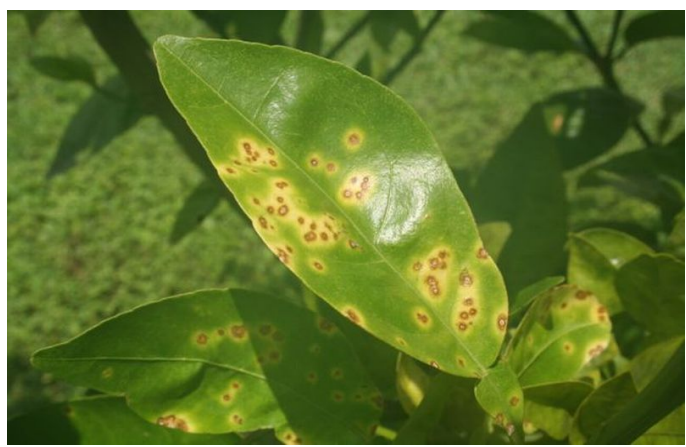

Figure 9.

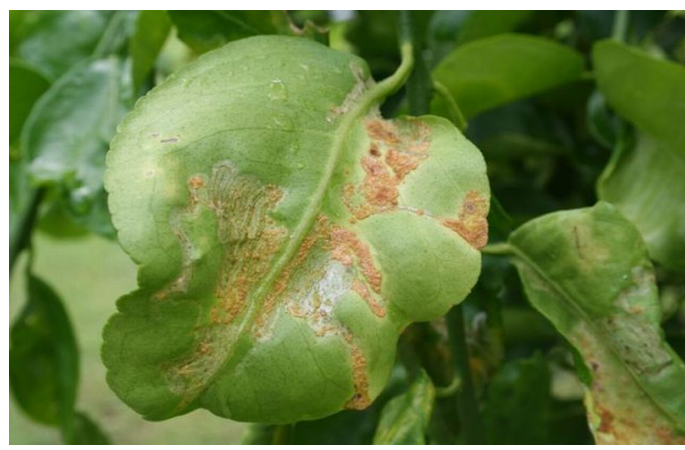

Figure 10.

\section{Causal Agent}

Canker is caused by the bacterium Xanthomonas axonopodis pv. citri. It is an obligate aerobe with yellow-pigmented colonies growing on most culture media. In media containing sugars, colonies produce extra-polysaccharides that make them mucoid (slimy).

\section{Disease cycle and Epidemiology}

Bacterial cells survive in lesions and to some extent in plant debris. When free moisture is present, bacteria cells ooze out of lesions and are dispersed short distances by wind-driven rain. Only young host tissue is susceptible to infection. Bacteria infect the plant through open stomata or wounds caused by wind-blown thorns and sand, leaf miners, or pruning. Optimal infection occurs at $68-86^{\circ} \mathrm{F}\left(20-30^{\circ} \mathrm{C}\right)$.

Bacteria on plant or soil surface do not survive very long do to sensitivity to UV light, but bacteria associated with plant debris can survive for several months, and cells in lesions can survive several years. $X$. axonopodis pv. citri has been associated with several weed species, but the role of weeds as an inoculum source is not known. High populations of the Asian leaf miner increase inoculum and disease levels.

Trees on less vigorous roots stocks and older trees often have less serious canker problems due to fewer and less frequent leaf flushes.

Long distance inoculum dispersal occurs mostly with infected propagative materials (budwood, rootstock seedlings), infested clothing and equipment, wooden harvest boxes, and the dumping of infected cull fruit close to orchards. Major weather events such as hurricanes and tornados can also transport inoculum long distances.

\section{Management}

Until recently, Florida had an eradication program in place for the disease. After the 2004-2005 hurricanes spread the disease beyond a controllable area of south Florida, the program was abandoned, and growers must now try managing the disease using several methods. 
One of the most effective methods of control is the installation of windbreaks, which not only decrease short distance dispersal of inoculum, but also decrease plant wounding due to wind-blown sand and debris. Planting inter-rows in a cover crop can also decrease plant wounding by decreasing the amount of sand or soil particles that can blow into the canopy. Planting in sites with high wind should be minimized, and work in groves should not be done under wet conditions. Pruning should be done in the dry season. All worker clothes and equipment should be disinfested before moving from a diseased to a healthy orchard.

Leaf miner control is important for minimizing canker levels. This can be achieved through insecticide applications. Copper sprays on young fruit should provide adequate protection from infections. Two to three treatments will be necessary during the first 90 days after petal drop, but 6 or more annual sprays may be necessary in wet years.

\section{Citrus Greening (Huanglongbing)}

Citrus greening is a serious disease widespread in Asia that was recently identified in Florida. Lemons and limes are more tolerant than other citrus types.

\section{Symptoms}

The earliest symptom of greening is the appearance of a yellowed shoot (Figure 11$)^{3}$. Individual leaves often have a mottled appearance and can have a deformed shape. On 'Tahiti' lime, mottled areas are larger than those on other citrus (Figure 12). Eventually the entire canopy yellows and trees die. What happens to fruit quality on 'Tahiti' lime has not been documented at this time.

\section{Causal Agent}

Greening is caused by the bacterium Candidatus Liberobacter spp. It is a phloem limited bacterium that has not been successfully cultured.

\section{Disease Cycle and Epidemiology}

The bacterium is transmitted primarily by the citrus psyllid, Diaphorina citri (Figure 13). Adults vector the disease, which can propagate in the insect.

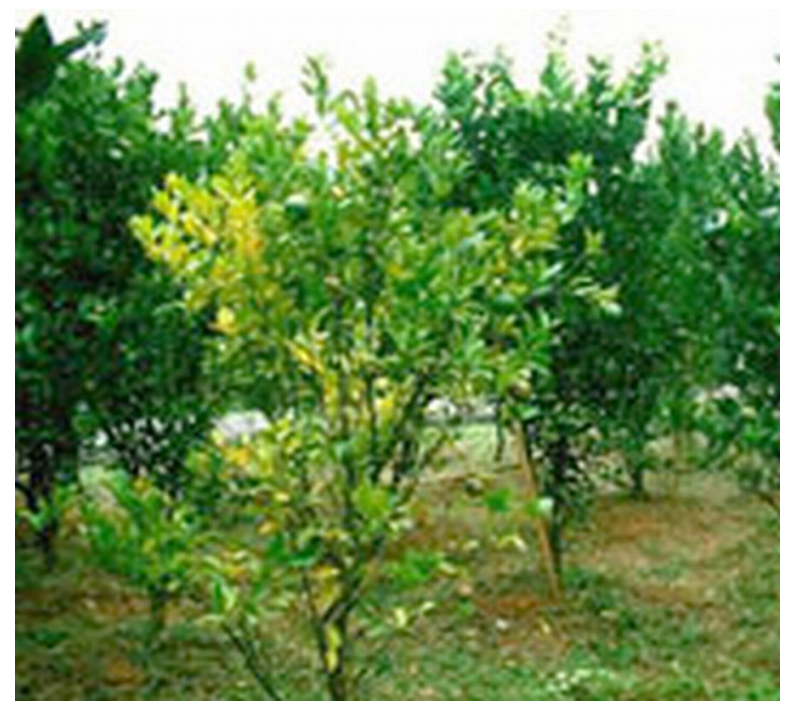

Figure 11.

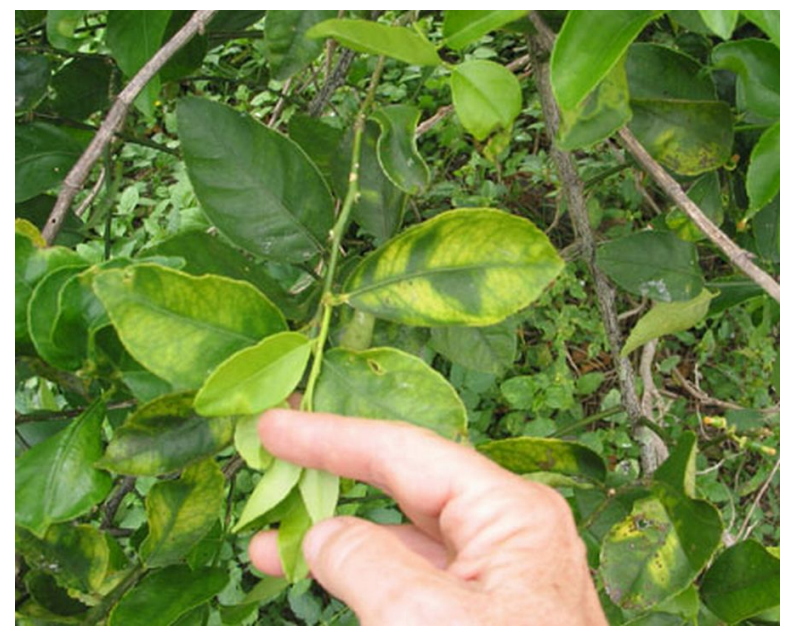

Figure 12.

Adults remain infective for several months.

Symptoms take 4-6 months to develop and symptoms can be hard to diagnose (they often resemble zinc deficiency). Therefore, symptomless but infected plants can be unknowingly distributed from nurseries, causing long distance spread of the disease).

Recent research has shown the disease can also be graft transmitted.

\section{Management}

The primary management tactic is chemical control of the citrus psyllid. In addition, biocontrol of the psyllid using parasitic wasps has been effective in some regions of the world. 


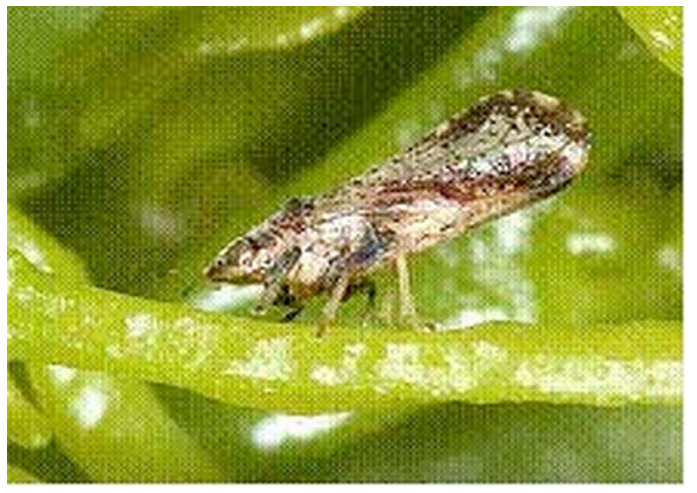

Figure 13.

Infected trees should be promptly removed from orchards, and only disease-free propagative material should be planted.

\section{ADDITIONAL DISEASES}

\section{ALGAL DISEASE (ALGA SPOT, RED ALGAL DISEASE)}

This disease is caused by a parasitic alga, Cephaleuros virescens. This organism has a wide host range among tropical and subtropical trees, but is a particularly serious problem on 'Tahiti' lime. Lesions on leaves are roughly circular, raised, and greenish-gray in color. The alga will eventually produce rust-colored microscopic "spores" on the surface of the leaf spots, giving the spots a reddish appearance (Figure 14). Severe leaf symptoms can cause defoliation.

The alga may also attack branches, and bark splitting may occur. If wood infections become severe, girdling and death of branches may result. The appearance of the masses of red "spores" on the wood (Figure 15) is highly diagnostic.

Algal disease can be prevented and controlled with copper sprays during the rainy season (June through August).

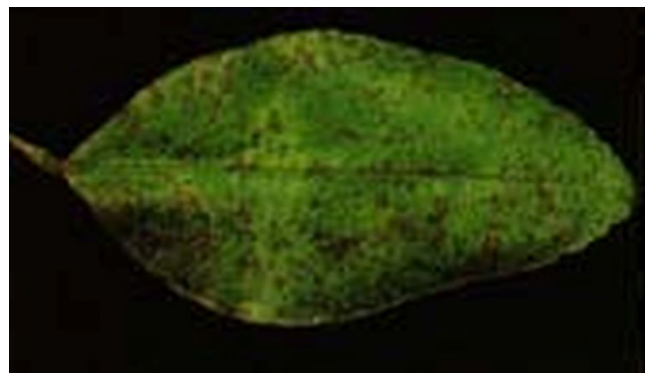

Figure 14.

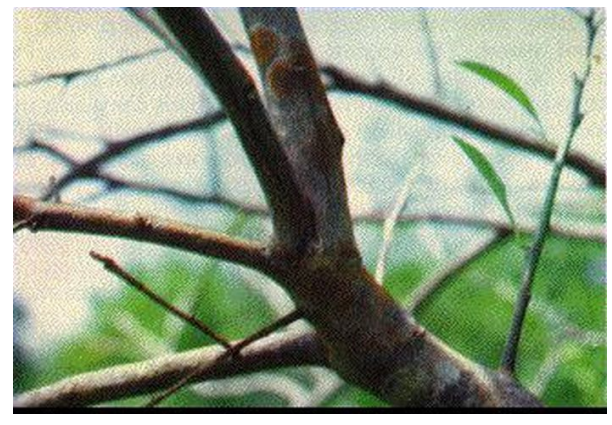

Figure 15.

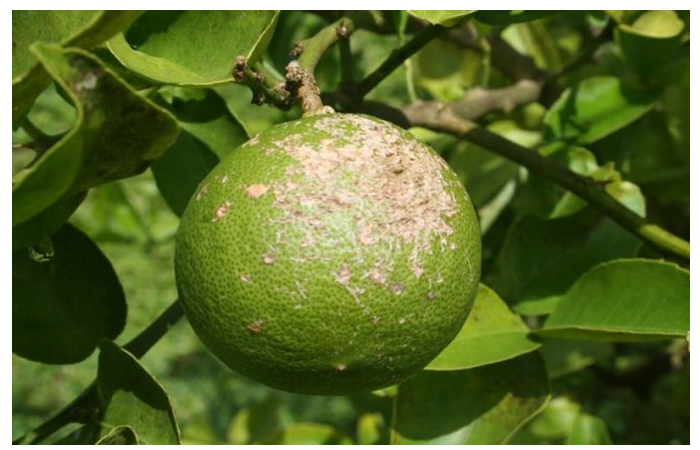

Figure 16.

\section{MECHANICAL DAMAGE}

Leaves, twigs, and thorns that rub against the rind of the fruit, especially under very windy conditions, can easily damage young fruit. The rubbing causes the rupture of oil glands that cause phytotoxic damage to the rind. These scars are usually grey in color and appear on the upper side of fruit (Figure 16). Installation of windbreaks can decrease mechanical damage. Growers occasionally report feeding by birds on mature fruit.

\section{References}

Gottwald, T.R., da Graça, J.V., and Bassanezi, R.B. 2007. Citrus huanglongbing: the pathogen and its impact. Plant Health Progress. doi:10.1094/PHP-2007-0906-01-RS

Gottwald, T.R.. Graham, J.H., and Schubert, T.S. 2002. Citrus canker: the pathogen and its impact. Plant Health Progress doi:10.1094/PHP-2002-0812-01-RV

Graham, J.H., and Timmer, L.W. 2009. 2009 Florida Citrus Pest Management Guide: Phytophthora Foot Rot and Root Rot. PP-156, Florida Cooperative Extension Service, IFAS, University of Florida. 
McCoy, C.W., Rogers, M.E., Futch, S.H., Graham, J.H., Duncan, L.W., and Nigg, H.N. 2009.

2009 Florida Citrus Pest Management Guide: Citrus

Root Weevils. ENY-611, Florida Cooperative

Extension Service, IFAS, University of Florida.

Mondal, S.N., and Timmer, L.W. 2006. Greasy spot, a serious endemic problem for citrus production in the Caribbean Basin. Plant Disease 95:532-538.

Timmer, L.W., Garnsey, S.M., and Broadbent, P. 2003. Diseases of Citrus. pp. 163-196 in Diseases of Tropical Fruit Crops, ed. R.C. Ploetz. CAB International; Cambridge, MA.

Timmer, L.W., Garnsey, S.M., and Graham, J.H. 2000. Compendium of Citrus Diseases, second edition. APS Press; Minneapolis, MN.

${ }^{3}$ Figures 11-13 used with permission from the United States Department of Agriculture's Animal and Plant Health Inspection Service (APHIS/USDA). 